UDC 614.7

DOI: 10.21668/health.risk/2018.1.09.eng

\title{
CONDITIONS WHICH CAUSE RISK FACTORS FOR RAILROAD TRANSPORT WORKERS AND POPULATION: HYGIENIC ASSESSMENT (ON THE EXAMPLE OF SOUTH-EASTERN RAILWAY)
}

\author{
V.A. Loginova ${ }^{1}$, G.G. Onishchenko ${ }^{2}$ \\ ${ }^{1}$ Federal Service for Surveillance over Consumer Rights Protection and Human Wellbeing, Railway transport \\ office, 17 Dubininskaya Str., Moscow, 115054, Russian Federation \\ ${ }^{2}$ Russian Academy of Sciences, 32a Leninskii prospect, Moscow, 119334, Russian Federation
}

We performed comparative hygienic assessment of environmental factors and health of population living near the South-Eastern railway and railroad transport workers over 21012-2016 and revealed a trend for environmental quality improvement both at railroad objects and on territories influenced by them. This trend was confirmed by a 3.8 times decrease in specific weight of atmospheric air samples with hazardous substances concentrations exceeding MPC; a decrease in drinking water samples taken from distribution networks which deviated from standards (by $31.5 \%$ as per sanitary-chemical parameters, and by $26.5 \%$, as per microbiological ones); lower share of soil samples not corresponding to standards (it went down to 0 as per sanitary-chemical parameters, and there was a 1.8 times decrease in it as per microbiological parameters); there was also a decrease in a number of workplaces not corresponding to hygienic standards in terms of physical factors (noise, by 1.6 times lower, microclimate, by 3.1 times, luminance, by 1.7 times) and in terms of MPC levels related to vapors and gases concentrations in working area air (by 4.3 times), as well as dust and aerosols (by 1.6 times). At the same time there are persistent negative trends for dynamic parameters of water reservoirs quality: a specific weight of water samples not corresponding to standards increased, by $3.4 \%$ as per sanitary-chemical parameters, and by $29.2 \%$, as per microbiological ones. Occupational risks for railroad transport workers still exist. Industrial noise is considered to be a priority risk factor and it corresponds to occupational morbidity structure. 19 occupational morbidity cases were detected at South-Eastern railway over the examined period. Occupational morbidity went down from 1.3 to 0.2 cases per 10000 workers (from 1.5 to 1.14 per 10000 workers for the whole railways network). Sensorineural hearing loss amounts to $63.2 \%$ in occupational pathology structure (up to $73 \%$ for the whole railways network). Working conditions of locomotive team members remain the most unfavorable.

Negative environmental factors continue to exert their influence on health. Although primary morbidity among population in general and workers employed by "Russian Railways" PLC ("RR" PLC) over 2012-2016 (by $13.1 \%$ and $13.6 \%$ correspondingly), an increase in respiratory organs diseases is detected both among population in general (by $11.2 \%$ ), and workers employed by "RR" PLC (by $18.5 \%$ ). Besides, respiratory organs diseases make the greatest contribution into primary morbidity. Their specific weight amounts to 26.5$39.8 \%$ among population in general, and to $37.9 \%$, among "RR" PLC workers. As a whole, morbidity among "RR" PLC workers employed at the South-Eastern railway tends to be 34.7-43.9\% higher than among population in general (by 24.3-36.4\% for the whole railways network), and this fact proves there are additional negative influences exerted by occupational factors. It is also shown that morbidity with temporary disability among 1 st category workers has a negative trend (a $5 \%$ increase).

Key words: environmental factors, primary morbidity, occupational diseases, railroad transport, hygienic assessment, occupational risk.

The World Health Organization states that the top priority among primary prevention tasks is to create and maintain a healthy environment. The environment is a most vital component in health protection, and various activities which are an essential part of it play an important role in risks determination. Examples of such activities are en-

(C) Loginova V.A., Onishchenko G.G., 2018

Vera A. Loginova - Deputy Director (e-mail: va-loginova@mail.ru; tel.: +7 (495) 633-27-19).

Gennadiy G. Onishchenko - Member of the Russian Academy of Sciences, Doctor of Medical Sciences, Professor, Assistant to the RF Government Head (e-mail: journal@,fcrisk.ru; tel.: +7 (495) 954-39-85). 
ergy production, industries, water supply and sanitation, agriculture, housing, and transport [1].

Results obtained in various research prove that physical environmental factors and contamination of atmospheric air, drinking water, and soils, are priority environmental factors which influence population health. More than $80 \%$ population live on territories which are exposed to complex chemical loads. Industrial factors also exert adverse effects on a worker's body and are risk factors causing various diseases evolvement. Hygienic assessment of factor influence performed within health risk analysis methodology is an instrument for efficient management of sanitaryepidemiologic situation [2-7].

As per data taken from state report on sanitary-epidemiologic welfare at railways in 2012-2016 there was a positive trend in environmental situation at objects influenced by railway transport. There was a 3.8 times decrease in a share of examined samples with MPC higher than the standard as per hazardous substances content in the atmospheric air and soils; drinking water quality in distribution networks also improved [8-10]. Morbidity with temporary disability apparently tended to go down [11-13].

Our research goal was both to perform hygienic assessment of sanitaryepidemiologic situation on railway transport objects, and to assess priority risk factors occurrence (on the example of the Southern-Eastern railway).

Data and methods. We examined dynamics in basic sanitary-epidemiologic parameters at the Southern-Eastern railway (as a typical region where a railway network is located) and compared them with overall parameters obtained for the whole railway network. Our examination and comparison was based on data taken from the state statis- tic reports issued in 2012-2016 by Rospotrebnadzor offices and bodies for railway transport. We performed this comparison in order to detect adverse environmental factors which exerted their influence on railway workers' health. We also conducted a comparative assessment of sanitaryepidemiologic situation concerning the following environmental objects: atmospheric air, communal and drinking water supply facilities, and soils, which were influenced by railway transport infrastructure; our assessment also included working conditions and occupational morbidity of workers with basic railway transport occupations. We analyzed health of such workers in the branch as per parameters of morbidity with temporary disability.

Results and discussion. Rospotrebnadzor's territorial offices and institutions in the railway transport sphere are organized in such a way that their structure reflects specific features of management and operation systems which exist at railway transport. The basic structural principles here are:

- objects under surveillance are often observed beyond a territory where an office is located as railways go through various Russian regions and railway structure is organized accordingly;

- surveillance and control are often performed allowing for the linear structure which is characteristic for the railway transport system;

- surveillance and control over safety and sanitary-epidemiologic welfare of passengers and cargo transportation are organized in such a way that they can be performed at any point at any route.

Railway Transport Office of the Federal Service for Surveillance over Consumer Rights Protection and Human Well-being is the central authority among surveillance and control bodies which represent federal 
state sanitary-epidemiologic surveillance over railway transport. Its main function is to supervise and coordinate structural bodies' activities aimed at providing sanitaryepidemiologic safety at railway transport objects and infrastructure; the function is performed via 15 regional Rospotrebnadzor offices at 15 railways in the Russian Federation $[14,15]$.

The Southern-Eastern railway is a branch of "Russian Railways" PLC ("RR" PLC). It is located in the center of the whole railways network, goes through the Centralno-Chrnozyomniy economic district and connects eastern regions and the Urals with the Central Russia, as well as northern, northern-western and central Russian regions with the North Caucasus, Ukraine, and Transcaucasia states. It is linked to several other railways: Moskovskaya, Kuybyishevskaya, Privolzhskaya, and NorthCaucasian one. Regional square it operates on is equal to about $160,000 \mathrm{~km}$ or $0.9 \%$ of the Russian Federation territory. The operational length of the Southern-eastern railway is equal to 4.3 thousand kilometers or $5 \%$ of the total railways length in the Russian Federation. $83.6 \%$ of cargo turnover is made due to electrical traction; the remaining transportations are made with thermal traction. The Southern-Eastern railway goes through 3 regions: Liskinskiy, Belgorodskiy, and Michurinskiy. At present 5 pairs of high quality long-distant trains run on it.

Basic cargoes which are transported by the Southern-Eastern railway include iron ores, ferrous metals, construction materials, agricultural products, oil, cement, chemical and mineral fertilizers, industrial raw materials, and flux materials.

The Southern-Eastern department of the Rospotrebnadzor's Railway Transport Office is responsible for surveillance over about $6.9 \%$ of the overall number of objects under surveillance which are included into the railways network structure (the number was 1.657 in 2016). The greatest specific weight in the objects structure belongs to communal objects $(34.9 \%)$ and industrial ones $(30.9 \%)$. Transport vehicles are about $9 \%$ of the total number; objects which deal with food products retailing and catering are about $23.9 \%$; children and teenagers facilities account for $1.3 \%$.

Over the analyzed period (2012-2016) specific weight of objects belonging to the 3rd group as per their sanitaryepidemiologic welfare (extremely unsatisfactory) decreased from $12.6 \%$ in 2012 to $10.0 \%$ in 2016; average parameter for the overall railways network was $9.1 \%$. The structure of the 3rd group objects is as follows: communal objects account for $31.9 \%$ (average network parameter is $34.9 \%$ ); industrial objects, 30.9\% (average network parameter is $20.8 \%$ ); food products retailing and catering, 23.9\% (average network parameter is 16.3\%); transport vehicles, 9.1\% (average network parameter is 21.4\%); children and teenagers facilities, 1.3\% (average network parameter is $1.9 \%$ ).

Atmospheric air quality at railway transport objects depends on their own location and hazardous chemical objects being located near railways. Besides, there are potential sources of chemical contamination which can pollute atmospheric air: large industrial enterprises in the railway transport sphere; petrochemicals storage facilities; open-air coal storage facilities; enterprises dealing with manufacturing and storing wooden sleepers; places where railway tanks are cleansed, washed, and steamed (when oil and petrochemicals are transported). Accidents which happen at railways can also contribute into environmental contamination when hazardous chemicals are transported. Chemicals emitted and spilt into the environment cause health risks for 
people who live in settlements located near places of such accidents [16].

We analyzed atmospheric air quality on territories influenced by the railway transport objects and revealed that its hygienic characteristics improved. Specific weight of samples with chemicals concentrations higher than MPC summarily as per all ingredients went down 3.8 times from 2012 to 2016 and amounted to $0.4 \%$. Concentrations higher than 5 MPC were registered in single cases (less than $0.01 \%$ ).

As per data obtained in route and field examinations performed on territories influenced by industrial enterprises in the railway transport sphere, there also was a positive trend in the air quality. A share of atmospheric air samples with hazardous substances concentrations higher than MPC decreased 7.5 times in terms of all the basic contaminants.

The data obtained during socialhygienic monitoring revealed that nitrogen oxides, carbon disulphide and sulfur oxides, carbon oxides, carbon black, saturated and unsaturated hydrocarbons were the basic contaminants which polluted atmospheric air on territories influenced by the railway transport [14,15]. Concentrations higher than MPC were most frequently registered for suspended substances $-2.5 \%$ examined samples (including concentrations 5 times higher than MPC in $0.01 \%$ cases); phenol and its derivatives, $1.4 \%$ (higher than 5 MPC in $0.01 \%$ cases): formaldehyde, $0.5 \%$ (higher than 5 MPC in $0.05 \%$ cases); hydrocarbons, $0.3 \%$ (higher than 5 MPC in $0.06 \%$ cases). Concentrations in the atmospheric air higher than MPC were also registered for sulfur dioxide $(1.0 \%)$, carbon monoxide $(0.9 \%)$, nitrogen dioxide $(0.8 \%)$, heavy metals $(0.4 \%)$, ammonia and carbon disulphide (0.2\%). In 2016 suspended substances concentrations which exceeded MPC were registered on territories influ- enced by the Southern-Eastern railway objects; there were $0.5 \%$ samples not corresponding to hygienic standards summarily as per all ingredients; $2.4 \%$ samples, as per suspended substances.

Drinking water is mostly supplied to the Southern-Eastern railway objects from underground water sources, just like to the whole railways network in general; 135 artesian wells account for $97.95 \%$ of all water sources. Specific weight of centralized water supply sources which didn't conform to the hygienic standards decreased by $24.6 \%$ from 2012 and amounted to $10.4 \%$ in 2016 at the railways network in general. As for the Southern-Eastern railway, we detected a reverse trend here: specific weight of centralized water supply sources not conforming to the hygienic standards increased by $66.4 \%$ from 2012 and amounted to $21.97 \%$. $79.2 \%$ cases of poor sanitary situation at water supply sources is caused by absence of sanitary protection zones or by violation of requirements to their organization. Besides, quality of water which comes from underground water sources at Southern Eastern railway is significantly poorer than at the railways network in general: specific weight of samples unsatisfactory as per sanitary-chemical parameters amounted to $30.8-42.6 \%$ in the analyzed period and was $16.8 \%$ higher than on average at the railways network (Table 1).

Specific weight of samples which were unsatisfactory as per microbiological parameters was considerably lower than at the railways network in general. However, if taken in dynamics, this parameter has an apparent deteriorating trend as water quality obviously gets poorer. Specific weight of unsatisfactory samples increased from $2.4 \%$ in 2012 to $3.1 \%$ in 2016 . But in spite of low quality water taken from water supply sources, $94.6 \%$ people who live near the Southern-Eastern railway are provided 
with good quality drinking water which is a bit higher than at the railways network in general $(94.2 \%)$.

Water quality assessment in distribution networks revealed that it improved both at the Southern-Eastern railway and at the railways network in general. Specific weight of water samples which were unsatisfactory as per sanitary-chemical parameters decreased from 23.8\% in 2012 to $16.3 \%$ in 2016 at the Southern-Eastern railway (from $17.6 \%$ to $16.7 \%$ at the railways network in general); as per microbiological parameters, from $4.9 \%$ to $3.6 \%$ (from 4.6 to $3.2 \%$ at the railways network in general). Unsatisfactory sanitarychemical parameters of water are caused by it being too hard and by high iron contents in it; they consequently lead to unsatisfactory organoleptic water properties.

We analyzed surveillance and control activities and revealed that a big quantity of water samples not conforming to standards, especially as per sanitary-chemical parameters, was caused by unsatisfactory situation at communal networks, their overall decay, and untimely repair and maintenance procedures. Low quality of distribution networks is due to their longterm operation, changing conditions at places where they are located, application of pipes without any anti-corrosion coats, and low quality lock valves which are used at distribution networks.

Oil and its products, heavy oil, diesel oil, lubricants, as well as remains of transported cargoes and industrial wastes, are the most widely-spread contaminants on territories where railway transport enterprises are located. Besides, there are other contaminants on these territories, such as crushed stone which can no longer be used in construction, ferrous metals scrap, dredged soil which remains after excavation, ash and slag, sleepers.

A number of soil samples not corresponding to sanitary-epidemiologic requirements as per sanitary-chemical, microbiological and parasitological parameters tends to grow on territories where settlements are located.

Assessment of soils quality and sanitary state performed at the SouthernEastern railway revealed that there was a descending trend in number of soil samples not corresponding to hygienic standards as per sanitary-chemical, microbiological, and parasitological parameters. but still chemical contamination in 20122016 was 2.7 times higher than on average at the railway network. Microbiological soils contamination was also $8.4 \%$ higher than at the railways network on average (Table 2).

Objects under surveillance which are included into the railway networks structure are specific, and most of them are objects belonging to the "RR" PLC and its branches and subsidiaries. Therefore, laboratory examinations of soils samples were conducted mostly in zones influenced by industrial enterprises and transport ( $71 \%$ of examined samples).

Table 1

Qualitative parameters of water taken from water sources at intake points

\begin{tabular}{|l|c|c|c|c|c|c|c|c|c|c|}
\hline \multirow{3}{*}{ Parameters } & \multicolumn{9}{|c|}{ Underground sources } \\
\cline { 2 - 11 } & \multicolumn{2}{|c|}{2012} & \multicolumn{2}{c|}{2013} & \multicolumn{2}{c|}{2014} & \multicolumn{2}{c|}{2015} & \multicolumn{2}{c|}{2016} \\
\cline { 2 - 11 } & $\begin{array}{c}\text { Whole } \\
\text { network }\end{array}$ & $\begin{array}{c}\text { S-E } \\
\text { railway }\end{array}$ & $\begin{array}{c}\text { Whole } \\
\text { network }\end{array}$ & $\begin{array}{c}\text { S-E } \\
\text { railway }\end{array}$ & $\begin{array}{c}\text { Whole } \\
\text { network }\end{array}$ & $\begin{array}{c}\text { S-E } \\
\text { railway }\end{array}$ & $\begin{array}{c}\text { Whole } \\
\text { network }\end{array}$ & $\begin{array}{c}\text { S-E } \\
\text { railway }\end{array}$ & $\begin{array}{c}\text { Whole } \\
\text { network }\end{array}$ & $\begin{array}{c}\text { S-E } \\
\text { railway }\end{array}$ \\
\hline Sanitary-chemical & 31,1 & 34,9 & 30,7 & 42,6 & 32,1 & 38,7 & 31,6 & 30,8 & 30,7 & 36,1 \\
\hline Microbiological & 6,6 & 2,4 & 6,04 & 3,9 & 6,0 & 2,2 & 5,5 & 1,5 & 4,9 & 3,1 \\
\hline
\end{tabular}

Note: S-E railway means Southern-Eastern railway 
Conditions which cause risk factors for railroad transport workers and population: hygienic assessment...

Table 2

Soil quality characteristics

\begin{tabular}{|c|c|c|c|c|c|c|c|c|c|c|c|}
\hline \multirow{2}{*}{\multicolumn{2}{|c|}{ Parameters }} & \multicolumn{5}{|c|}{$\begin{array}{l}\text { Specific weight of samples not } \\
\text { conforming to hygienic standards }\end{array}$} & \multicolumn{5}{|c|}{ In settlements } \\
\hline & & 2012 & 2013 & 2014 & 2015 & 2016 & 2012 & 2013 & 2014 & 2015 & 2016 \\
\hline \multirow[t]{2}{*}{ Sanitary-chemical } & overall & 5,0 & 3,9 & 5,3 & 5,9 & 2,0 & 0,6 & 0,5 & 0,5 & 2,6 & 2,7 \\
\hline & SUR & 20,97 & 12,8 & 16,4 & 12,2 & $\mathbf{0}$ & $\mathbf{0}$ & $\mathbf{0}$ & $\mathbf{0}$ & $\mathbf{0}$ & $\mathbf{0}$ \\
\hline \multirow[t]{2}{*}{ Micro-biological } & overall & 3,9 & 3,3 & 8,8 & 3,2 & 3,3 & 4,3 & 3,4 & 16,5 & 2,9 & 3,7 \\
\hline & SUR & 10,6 & 4,4 & 4,0 & 4,1 & 5,7 & $\mathbf{0}$ & $\mathbf{0 , 8}$ & $\mathbf{0}$ & 1,2 & $\mathbf{0}$ \\
\hline \multirow[t]{2}{*}{ Parasitological } & overall & 2,0 & 1,7 & 1,9 & 0,4 & 0,3 & 1,0 & 1,1 & 0,73 & 0,4 & 0,4 \\
\hline & SUR & 1,4 & 1,2 & $\mathbf{0}$ & 1,5 & 1,1 & $\mathbf{0}$ & $\mathbf{0}$ & $\mathbf{0}$ & $\mathbf{0}$ & $\mathbf{0}$ \\
\hline
\end{tabular}

Note: SUR means Southern-Eastern railway

The highest chemical contamination was detected in such zones (16.8\% samples not conforming to hygienic standards), oil products and heavy metal salts being priority contaminants.

Objects under surveillance which are included into the railway networks structure are specific, and most of them are objects belonging to the "RR" PLC and its branches and subsidiaries. Therefore, laboratory examinations of soils samples were conducted mostly in zones influenced by industrial enterprises and transport ( $71 \%$ of examined samples). The highest chemical contamination was detected in such zones $(16.8 \%$ samples not conforming to hygienic standards), oil products and heavy metal salts being priority contaminants.

We analyzed primary morbidity among population who were exposed to the railways network impacts in dynamics over the examined period (2012-2016) and revealed there was a slight increase in the overall morbidity equal to $0.07 \%$. Population morbidity on territories influenced by the Southern-Eastern railway decreased by $13.1 \%$. Morbidity structure as per basic nosologies didn't change. Such nosologic forms as respiratory organs diseases (26.5$39.8 \%$ ), injuries, intoxications, and other outer causes (10.7-11.8\%), urogenital system diseases (7.5-9.7\%), ear and mastoid diseases (7.5-9.4\%), skin and subcutaneous tissue diseases $(6.2-7.8 \%)$ made the greatest contribution into primary morbidity both at the Southern-Eastern railway, and at the railways network in general.

Workers employed by "RR" PLC and its brunches and subsidiaries account for $32.9 \%$ among population influenced by railway transport objects at the SouthernEastern railway $(37.2 \%$ on average at the railways network in general). Therefore, assessment of hazardous influence exerted by specific industrial factors on railway workers is a significant part of hygienic monitoring $[17,18]$.

Railway objects include repairing plants, repairing depots for locomotives and carriages, railways maintenance stations, communication, and power supply stations. Their analysis performed at the Southern-Eastern railway revealed that specific weight of objects belonging to the 3rd sanitary-epidemiologic category (extremely unsatisfactory) decreased from $19.7 \%$ in 2012 to $11.5 \%$ in 2016 . Besides, we noted that a share of such 3rd category objects was on average $17.3 \%$ lower that at the railways network in general.

Laboratory examination of working area air performed in 2012-2016 revealed there was a descending trend in specific weight of samples with steams and gases concentrations higher than MPC, both in general, and in terms of substances belonging to the 1-2 hazard category (from 2.6 to $0.6 \%$ and from 2.3 to $1.9 \%$ corresponding1y). This dynamics is also true for the railways network in general. As working area air quality improves due to decrease in dust 
and aerosols contents at the SouthernEastern railway objects, specific weight of air samples with dust and aerosols contents exceeding MPC goes down from 10.9 to $6.8 \%$; as for substances belonging to the 12 hazard category, from 8.9 to $0.9 \%$. There is a reverse trend at the railways network in general: specific weight of samples with dust and aerosols concentrations higher than MPC increased from 13.5 to $15.3 \%$; as for substances belonging to the 12- hazard category, from 13.5 to $22.6 \%$ [19,20].

There was a decrease in specific weight of working places not corresponding to hygienic standards at industrial objects related to the Southern-eastern railway; the same trend was detected at the railways network in general. Here are the figures for several parameters: 1) noise level, a drop from $30.3 \%$ to $18.5 \%$ (at the railways network in general from $21.4 \%$ to $19.97 \%)$; 2) microclimate, from 56.0 to $1.6 \%$ (from 5.3 to $4.6 \%$ ); luminosity, from 15.6 to $9.2 \%$ (from 19.6 to $16.9 \%$ ). But as for vibration, specific weight of working place where this parameter didn't conform to hygienic standards increased from 8.1 to $9.3 \%$ while the average railways network parameter decreased from 17.7 to $10.99 \%$ [19,20].

Our analysis of control and surveillance activities results revealed that there were several factors causing unsatisfactory working conditions inside industrial facilities, namely: machine tools (metal processing units, wood processing ones, forging machines etc.) were in operation for very long time periods, and their wear and tear was great; ventilation either was absent at working places or didn't function properly; in some cases, ventilation systems were not constructed relevantly and with any allowance for production processes peculiarities (incorrect technical solutions); temperature regime was unbalanced (not enough heating units in work- shops, or heating systems didn't function in tact with gates opening); improper ventilation during welding; most hazardous processes were not isolated.

Occupational morbidity had an apparent descending trend. From 2012 to 2016 a number of detected occupational diseases decreased from 133 cases to 97 cases, and morbidity index fell from 1.5 to 1.14 per 10,000 workers (the average country index was 1.47 per 10,000 workers in 2016) [16].

Occupational morbidity structure doesn't change significantly in terms of occupations and nosologic forms. Locomotive drivers and their assistants have the greatest share in it (32.5-51.5\%), as well as track walkers who check railways (19.3$24.3 \%$ ). Sensorineural hearing loss holds the leading place among diseases (up to $73 \%$ ); the second place belong to diseases with dust etiology (up to $13 \%$ ); vibration disease takes the third place (up to $5 \%$ ). Peripheral nervous system (PNS) diseases and musculoskeletal system diseases are at the fourth place (up to $9 \%$ together).

There are peculiarities in occupational morbidity among locomotive teams members; they are determined by their specific working conditions. The greatest share among diseases here belongs to sensorineural hearing loss (93.4\%); vibration disease has the second place $(9.4 \%)$, and peripheral nervous system (PNS) diseases and musculoskeletal system diseases are at the third place $(1.3 \%)$ [8-10].

Over 2012-2016 single cases of occupational diseases were registered among workers employed at the Southern-Eastern railway: $7,2,5,4,1$ correspondingly, and $47.4 \%$ cases were registered among locomotive drivers. Sensorineural hearing loss prevails in occupational pathology structure with its specific weight being 63.2\%; respiratory organs diseases account for $26.3 \%$, and musculoskeletal system diseases, for $10.5 \%$. 
There is an overall descending trend in primary morbidity among workers employed by "RR" PLC, both at the SouthernEastern railway $(-13.6 \%)$, and at the railways network in general $(-8.8 \%)$. Primary morbidity detected at the Southern-Eastern railway is on average $6.99 \%$ lower that at the railways network in general and amounts to 528,1\%o. However, overall morbidity index among "RR" PLC workers at the Southern-Eastern railway is 34.7$43.9 \%$ higher than among the RF population in general (24.3-36.4\% higher among workers at the railways network in general).

Primary morbidity structure for "RR" PLC workers is as follows: the leading place belongs to respiratory organs diseases with $37.3 \%$ at the Southern-Eastern railway and $36.9 \%$ at the railways network in general; injuries, intoxications and other outer causes have the second place and account for $13.1 \%$ and $13.7 \%$ correspondingly; skin and subcutaneous tissue diseases have the third place and account for $10.4 \%$ and $6.5 \%$ (it is the 5 th place at the railways network in general) correspondingly. The fourth place belongs to urogenital system diseases with $6.6 \%(9.7 \%$ and the third place at the railways network in general); the fifth place is musculoskeletal system diseases which account for $4.4 \%$ (6.9\% and the fourth place at the railways network in general). Besides, we detected a $18.5 \%$ increase in primary morbidity with respiratory organs diseases, and a $4.3 \%$ increase, with digestive organs diseases.

We analyzed morbidity with temporary disability over 2012-2016 and revealed that a number of temporary disability cases per 100 workers fell from 52.4 to 48.5, and a number of days, from 652.4 to 605.1 . At the same time, a number of temporary disability cases per 100 workers increased by $5.9 \%$ (from 52.7 to 55.8 ) among the 1 st category workers (those directly re- sponsible for trains movement), but a number of days in a temporary disability period per 100 workers decreased by $3.3 \%$.

Conclusion. So, we can conclude that the environment in zones influenced by the Southern-Eastern railway improved over 2012-2016. Improvements were detected as per most analyzed factors. Atmospheric air quality improved in terms of chemicals concentrations (specific weight of samples with concentration higher than MPC decreased 3.8 times and 7.5 times in zones influenced by industrial enterprises). Drinking water quality in distribution networks also improved (a number of samples unsatisfactory as per sanitary-chemical parameters decreased by $31.5 \%$, and microbiological ones, by $26.5 \%$ ), as well as soil quality (a number of samples not conforming to hygienic standards as per sanitarychemical parameters fell down to 0 , and decreased 1.8 times as per microbiological ones). Working conditions for workers employed in the railway transport branch became safer as specific weight of samples with stem and gases concentrations higher than MPC dropped 4.3 times; aerosols and dust, 1.6 times; number of working places not conforming to hygienic standards in terms of noise decreased 1.6 times; microclimate, 3.1 times, luminosity, 1.7 times.

There was a positive trend in the examined period in overall ranking of railways transport objects and transport infrastructure in terms of their sanitaryepidemiologic state: a share of the 3rd category objects (extremely unsatisfactory ones) dropped by $20.6 \%$.

But still, there are negative trends in some areas: quality of water taken from underground sources remains poor (a number of water sources not conforming to hygienic standards increased by $66.4 \%$; number of water samples which were unsatisfactory as per sanitary-chemical parameters grew by $3.4 \%$, and as per microbiological 
ones, by $29.2 \%$ ). Working places didn't correspond to safety standards in terms of vibration (and the share of such working places grew by $14.8 \%$ ).

Occupational risk for railway workers also remains. Industrial noise is a priority risk factor and it corresponds to occupational morbidity structure. 19 occupational diseases cases were detected in the examined period at the Southern-Eastern railway. Occupational morbidity index decreased from 1.3 to 0.2 per 10,000 workers (from 1.5 to 1.14 per 10,000 workers at the railways network in general). Sensorineural hearing loss accounts for $63.2 \%$ in occupational morbidity structure (up to $73 \%$ at the railways network in general). Locomotive teams members have to work in the most unsatisfactory working conditions.
Environmental factors continue to exert negative influence. Although primary morbidity decreased both among population in general and among workers employed by "RR" PLC over 2012-2016 (by $13.1 \%$ and $13.6 \%$ correspondingly), morbidity with respiratory organs diseases grew both among population in general (by $11.2 \%$ ), and among "RR" PLC workers (by $18.5 \%$ ). Besides, respiratory organs diseases make the greatest contribution into primary morbidity with their specific weight being equal to $26.5-39.8 \%$ (37.9\% among the "RR" PLC workers). Overall, morbidity among "RR" PLC workers employed at the Southern-Eastern railway tends to be higher than among population in general by $34.7-43.9 \%$ (by $24.3-36.4 \%$ at the railways network in general), and it proves there is additional negative influence exerted by adverse industrial factors.

\section{References}

1. Prüss-Ustün A., Wolf J., Corvalán C., Bos R., Neira M. Preventing disease through healthy environments: A global assessment of the burden of disease from environmental risks. World Health Organization, 2016, 176 p. Available at: http://apps.who.int/iris/bitstream/10665/204585/1/9789241565196 eng.pdf?ua=1 (19.02.2018).

2. Onishchenko G.G., Zaitseva N.V., May I.V. [et al.]. Analiz riska zdorov'yu v strategii gosudarstvennogo sotsial'no-ekonomicheskogo razvitiya: monografiya [Health risk analysis in the strategy of state social and economical development: monograph]. In: G.G. Onishchenko, N.V. Zaitseva, eds. Moscow, Perm', 2014, pp. 552-561, 634-650 (in Russian).

3. Zaitseva N.V., May I.V., Shur P.Z. Analiz riska zdorov'yu naseleniya na sovremennom etape [Contemporary population health risk analysis]. Zdravookhranenie Rossiiskoi Federatsii, 2013, no. 2, pp. 20-24 (in Russian).

4. Borovkova A.M., Kladova T.V., Lazareva Yu.A. Otsenka professional'nogo riska dlya rabotnikov zheleznodorozhnogo transporta [Occupational Health Risk Assessment for Rail Transport Workers]. Sibbezopasnost'-Spassib, 2013, no. 1, pp. 26-32 (in Russian).

5. Zaitseva N.V., May I.V., Andreeva E.E., Kleyn S.V., Alekseeva A.V. Metodicheskie i prakticheskie aspekty dokazatel'stva realizatsii riskov, formiruemykh negativnym vozdeistviem faktorov sredy obitaniya [Methodical and practical aspects related to confirming realization of risks caused by negative environmental factors influence]. Aktual'nye problemy bezopasnosti $i$ analiza riska zdorov'yu naseleniya pri vozdeistvii faktorov sredy obitaniya: sbornik materialov VII Vserossiiskoi nauchno-prakticheskoi konferentsii s mezhdunarodnym uchastiem [Vital issues of safety and population health risk analysis under exposure to environmental factors: materials collected for VII Russian theoretical and practical conference with international participation]. In: A.Yu. Popova, N.V. Zaitseva, eds. Perm', 2016, vol. 1, pp. 73-80 (in Russian). 
6. Rakhmanin Yu.A., Mikhailova R.I. Okruzhayushchaya sreda i zdorov'e: prioritety profilakticheskoi meditsiny [Environment and Health: Priorities for Preventive Medicine]. Gigiena $i$ sanitariya, 2014, vol. 93, no. 5, pp. 5-10 (in Russian).

7. Onishchenko G.G. O sanitarno-epidemiologicheskom sostoyanii okruzhayushchei sredy [On Sanitary and Epidemiological State of The Environment]. Gigiena i sanitariya, 2013, no. 2, pp. 4-10 (in Russian).

8. O sanitarno-epidemiologicheskoi obstanovke na zheleznodorozhnom transporte v 2012 godu: Gosudarstvennyi doklad [On sanitary-epidemiologic situation on railroad transport in 2012: State Report]. Moscow, Upravlenie Federal'noi sluzhby po nadzoru v sfere zashchity prav potrebitelei i blagopoluchiya cheloveka po zheleznodorozhnomu transportu Publ., 2012, 80 p. Available at: $\quad$ http://urpngt.rospotrebnadzor.ru/files/docs/doklads/gosdoklad 2012.doc (23.01.2018) (in Russian).

9. O sanitarno-epidemiologicheskoi obstanovke na zheleznodorozhnom transporte v 2014 godu: Gosudarstvennyi doklad [On sanitary-epidemiologic situation on railroad transport in 2014: State Report]. Moscow, Upravlenie Federal'noi sluzhby po nadzoru v sfere zashchity prav potrebitelei i blagopoluchiya cheloveka po zheleznodorozhnomu transport Publ., 2015, 43 p. Available at: http://urpngt.rospotrebnadzor.ru/files/docs/doklads/gosdoklad_2014.doc (23.01.2018) (in Russian).

10. O sostoyanii sanitarno-epidemiologicheskogo blagopoluchiya na zheleznodorozhnom transporte v 2016 godu: Gosudarstvennyi doklad [On sanitary-epidemiologic welfare on railroad transport in 2016: State Report]. Moscow, Upravlenie Federal'noi sluzhby po nadzoru v sfere zashchity prav potrebitelei i blagopoluchiya cheloveka po zheleznodorozhnomu transport Publ., 2017, 53 p. Available at: http://urpngt.rospotrebnadzor.ru/files/docs/ doc2017/Gosdoklad sost sanepid 2016.doc (24.01.2018) (in Russian).

11. Zdorov'e rabotnikov OAO «RZhD», chlenov semei rabotnikov OAO «RZhD», nerabotayushchikh pensionerov OAO «RZhD» i territorial'nogo naseleniya v 2012-2013 gg. ["RR" PLC workers and their family members' health; health of retired "RR" PLC workers and health of population living on territories exposed to railroads influence, in 2012-2013]. Deyatel'nost' negosudarstvennykh uchrezhdenii zdravookhraneniya OAO «RZhD» v 2012-2013 gg.: sbornik statisticheskikh materialov [Activities of "RR" PLC non-state healthcare organizations in 20122013: statistic materials collection]. Moscow, 2014, 243 p. (in Russian).

12. Pokazateli sostoyaniya zdorov'ya rabotnikov OAO «RZhD», chlenov semei rabotnikov $\mathrm{OAO}$ «RZhD», nerabotayushchikh pensionerov $\mathrm{OAO}$ «RZhD» i prikreplennogo territorial'nogo naseleniya v 2014-2015 gg. ["RR" PLC workers and their family members' health; health of retired "RR" PLC workers and health of population living on territories exposed to railroads influence, in 2014-2015]. Deyatel'nost' negosudarstvennykh uchrezhdenii zdravookhraneniya OAO «RZhD»v 2014-2015 gg.: sbornik statisticheskikh materialov [Activities of "RR" PLC nonstate healthcare organizations in 2014-2015: statistic materials collection]. Moscow, 2016, 273 p. (in Russian).

13. Pokazateli sostoyaniya zdorov'ya rabotnikov OAO «RZhD», nerabotayushchikh pensionerov OAO «RZhD» i prikreplennogo territorial'nogo naseleniya v 2016 godu ["RR" PLC workers and their family members' health; health of retired "RR" PLC workers and health of population living on territories exposed to railroads influence, in 2016]. Deyatel'nost' negosudarstvennykh uchrezhdenii zdravookhraneniya OAO «RZhD»v 2016 godu: sbornik statisticheskikh materialov [Activities of "RR" PLC non-state healthcare organizations in 2016: statistic materials collection]. Moscow, 2017, 263 p. (in Russian).

14. Kas'kov Yu.N. Nauchnoe obosnovanie i realizatsiya sistemy prioritetnykh mer po obespecheniyu sanitarno-epidemiologicheskogo blagopoluchiya na zheleznodorozhnom trans- 
porte v usloviyakh administrativnoi reformy: avtoref. dis... doktora med. Nauk [Scientific foundations and implementation of priority activities aimed at providing sanitary-epidemiologic safety at railroad transport during administrative reforming: abstracts of a thesis... Doctor of Medical Sciences]. Moscow, 2014, 232 p. (in Russian).

15. Farkhatdinov G.A., Kas'kov Yu.N., Podkorytov Yu.I., Svitenko O.A. Aktual'nye voprosy obespecheniya sanitarno-epidemiologicheskoi bezopasnosti passazhirskikh i gruzovykh perevozok zheleznodorozhnym transportom Rossii [The actual problems of supply of sanitarium and epidemiological safety of passenger and goods transportation by russian railways]. Dezinfektsiya. Antiseptika, 2014, vol. 5, no. 2, pp. 28-32 (in Russian).

16. Kas'kov Yu.N., Podkorytov Yu.I. K sovremennomu sostoyaniyu khimicheskogo zagryazneniya okruzhayushchei sredy na ob"ektakh zheleznodorozhnogo transporta Rossii [The Current State of Environmental Chemical Pollution In Russian Railway Transport Facilities]. Meditsina truda i ekologiya cheloveka, 2016, no. 4, pp. 91-97 (in Russian).

17. Kaptsov V.A., Mezentsev A.P., Pankova V.B. Proizvodstvenno-professional'nyi risk zheleznodorozhnikov [Occupational railroad workers risk]. Moscow, 2002, pp. 206-207 (in Russian).

18. Loginova V.A. Gigienicheskaya otsenka uslovii truda i professional'nogo riska zdorov'yu rabotnikov na ob"ektakh zheleznodorozhnogo transporta [Hygienic assessment of working conditions and occupational risk for workers health at railway transport objects]. $A n-$ aliz riska zdorov'yu, 2017, no. 2, pp. 96-101. DOI: 10.21668/ health.risk/2017.2.10.eng

19. Analiz sanitarno-gigienicheskogo sostoyaniya promyshlennykh predpriyatii zheleznodorozhnogo transporta i professional'noi zabolevaemosti za 2014 g.: Informatsionnyi byulleten' [Analysis of sanitary-hygienic situation at railroad transport and occupational morbidity in 2014: Information bulletin]. Moscow, Upravlenie Rospotrebnadzora po zheleznodorozhnomu transportu, FBUZ «Tsentr gigieny i epidemiologii po zheleznodorozhnomu transportu» Publ., 2015, 23 p. (in Russian).

20. Analiz sanitarno-gigienicheskogo sostoyaniya promyshlennykh predpriyatii zheleznodorozhnogo transporta i professional'noi zabolevaemosti za 2016 g.: Informatsionnyi byulleten' [Analysis of sanitary-hygienic situation at railroad transport and occupational morbidity in 2016: Information bulletin]. Moscow, Upravlenie Rospotrebnadzora po zheleznodorozhnomu transportu, FBUZ «Tsentr gigieny i epidemiologii po zheleznodorozhnomu transportu» Publ., 2017, 21 p. (in Russian).

Loginova V.A., Onishchenko G.G. Conditions which cause risk factors for railroad transport workers and population: hygienic assessment (on the example of South-Eastern Railway). Health Risk Analysis, 2018, no. 1, pp. 78-88. DOI: 10.21668/health.risk/2018.1.09.eng

Received: 28.02 .2018

Accepted: 12.03 .2018

Published: 30.03.2018 